特集 1

5 年生存例の解析からみた食道癌治療上の問題点

\author{
国立がんセンター病院外科 \\ 飯塚 紀文加藤抱一
}

\title{
PROBLEMS CONCERNING THE TREATMENT FOR ESOPHAGEAL CARCINOMA FROM THE OBSERVATION ON 5-YEAR SURVIVORS
}

\section{Toshifumi IIZUKA and Hoichi KATO}

National Cancer Center Hospital, Tokyo

察引用語: 食道癌 5 生率, 食道癌術後再発, 重䘸癌

\section{1.はじめに}

食道癌は治療成績の劣っている癌の一つであり, 治 療成績向上のための努力が必要である．現在食道癌の 治療には外科手術が主たる治療法として行われている が, 術前後照射, 更にこれに化学療法を併用するなど， 治療成績向上のための併用療法が行われている。

併しながら，食道癌の予後を規定するのはどのよ5 な因子があるのか，については多くの角度からの研究 が必要であ万う。今回は術後 5 年以上生存した症例と, 5 年以内に死亡した症例とを比較検討して，術後長期 生存に関する因子について考察した。

\section{2. 症例}

症例は1962年から1978年までに国立がんセンター病 院で切除手術を行った509例である.このうち, 手術死 亡は39例 (7.7\%)にみられた。この手術死亡を除いた 470例を予後検索の対象とした. 5 年生存例は96例であ り， 5 生率は $20.4 \%$ であった. 5 年生存の 96 例と 5 年 以内に死亡した374例について, 種々の因子から検討し た.

\section{3. 成 續}

性：表1にみられるように症例は男性が圧倒的に多 いため，5生例は男性の方が多いが，5生率をみると 男性が $17 \%$ であるのと性が $35.6 \%$ と有意に高値を示 した.

年龄：切除時の年龄と 5 生率をみると，表 2 にみら

※第24回日消外会総会シンポＩ：遠隔成績よりみた食 道癌治療上の問題点

$<1984$ 年11月 12 日受理 >別刷請求先：飯塚 紀文

厂104 中央区築地 5-1-1 国立がんセンター外 科
表 1 性差と 5 生例

\begin{tabular}{c|c|c|c}
\hline & 5 生例 & $\begin{array}{c}\text { 5 年以内 } \\
\text { 死亡例 }\end{array}$ & 5 生率 \\
\hline 男 性 & $65(67.7 \%)$ & $318(85.0 \%)$ & $(17.0 \%)$ \\
女 性 & $31(32.3 \%)$ & $56(15.0 \%)$ & $(35.6 \%)$ \\
\hline 計 & 96 & 374 & \\
\hline
\end{tabular}

表 2 年龄と 5 生例

\begin{tabular}{c|c|r|c}
\hline & 5 生例 & \multicolumn{1}{|c|}{$\begin{array}{c}\text { 5 年以内 } \\
\text { 死亡例 }\end{array}$} & 5 生率 \\
\hline-49 & $14(14.5 \%)$ & $37(9.9 \%)$ & $(27.5 \%)$ \\
$50-59$ & $35(36.5 \%)$ & $97(25.9 \%)$ & $(26.5 \%)$ \\
$60-69$ & $38(39.6 \%)$ & $182(48.7 \%)$ & $(16.5 \%)$ \\
$70-$ & $9(9.4 \%)$ & $58(15.5 \%)$ & $(13.4 \%)$ \\
\hline 計 & 96 & 374 & \\
\hline
\end{tabular}

れるよらに，40代と50代とが良く，60代，70代になる と低下している，今まで若い人の癌の予後は悪いとい われていいたが，食道癌では比較的若年者の方が良い という結果であった。

癌占居部位：占居部位別にみたのが表 3 である. Im と Ei が症例数が多いが，5生率には注とんど差がな い. Ce と Ea が高い生存率を示しているが症例数が少 ない.

$\mathrm{X}$ 線の陰影欠損の長さ：表 4 のように長さの順にみ てみると、長さが長くなるはど 5 生率は低下する. $5 \mathrm{~cm}$ までの群と $9 \mathrm{~cm}$ までの群の間には差があり, $9 \mathrm{~cm}$ 以上 になると著明に低下する，また，5生例の方が長さの 短いものの頻度が高い.

X線型：食道癌取扱い規的に従って分類すると，い 
表 3 占居部位と 5 生例

\begin{tabular}{l|r|r|c|}
\hline & 5 生例 & \multicolumn{1}{|c|}{$\begin{array}{c}\text { 5 年以内 } \\
\text { 死亡例 }\end{array}$} & 5 生率 \\
\hline $\mathrm{Ce}$ & $2(2.1 \%)$ & $2(0.5 \%)$ & $(50.0 \%)$ \\
$\mathrm{Iu}$ & $3(3.1 \%)$ & $25(6.7 \%)$ & $(10.7 \%)$ \\
$\mathrm{Im}$ & $57(59.4 \%)$ & $231(61.8 \%)$ & $(19.8 \%)$ \\
$\mathrm{Ei}$ & $29(30.2 \%)$ & $113(30.2 \%)$ & $(20.4 \%)$ \\
$\mathrm{Ea}$ & $5(5.2 \%)$ & $3(0.8 \%)$ & $(62.5 \%)$ \\
\hline 計 & \multicolumn{1}{|c|}{96} & 374 & \\
\hline
\end{tabular}

表 4 X線の長往と 5 生例

\begin{tabular}{c|c|r|c}
\hline & 5 生例 & $\begin{array}{c}5 \text { 年以内 } \\
\text { 死亡例 }\end{array}$ & 5 生率 \\
\hline$-3 \mathrm{~cm}$ & $10(10.4 \%)$ & $17(4.5 \%)$ & $(37.0 \%)$ \\
$3-5 \mathrm{~cm}$ & $29(30.2 \%)$ & $74(19.8 \%)$ & $(28.1 \%)$ \\
$5-7 \mathrm{~cm}$ & $31(32.3 \%)$ & $130(34.8 \%)$ & $(19.3 \%)$ \\
$7-9 \mathrm{~cm}$ & $21(21.9 \%)$ & $89(23.8 \%)$ & $(19.1 \%)$ \\
$9-$ & $5(5.2 \%)$ & $64(17.1 \%)$ & $(7.2 \%)$ \\
\hline 計 & 96 & 374 & \\
\hline
\end{tabular}

ずれの群でもらせん型が多いが，表層型，鋸歯型，腫 瘤型の頻度は 5 生例に多い(表 5). 従ってこのような 型のものが長期生存するものと思われる。

組織学的外膜浸潤の程度: 切除標本について組織学 的外膜漫潤の程度と生存とを検討した（表 6 )。 $a_{0}$ は最 も良く， $a_{1}$ と $a_{2}$ との間には差がなく， $a_{3}$ になると低下 した. $a_{0}$ の占める率は 5 生例では $45.8 \%$ であるが, 5 年

表 5 X線型と 5 生例

\begin{tabular}{|c|c|c|c|}
\hline & 5 年例 & $\begin{array}{l}5 \text { 年以内 } \\
\text { 死亡例 }\end{array}$ & 5 生率 \\
\hline 表 層 型 & $6(6.3 \%)$ & $4(1.1 \%)$ & $(60.6 \%)$ \\
\hline 鋸霜型 & $21(21.8 \%)$ & $69(18.4 \%)$ & $(23.3 \%)$ \\
\hline らせん型 & $40(41.7 \%)$ & $246(65.8 \%)$ & $(14.0 \%)$ \\
\hline ろーと型 & $5(5.2 \%)$ & $18(4.8 \%)$ & $(21.7 \%)$ \\
\hline 腫 瘤 型 & $24(25.0 \%)$ & $37(9.9 \%)$ & $(39.3 \%)$ \\
\hline 計 & 96 & 374 & \\
\hline
\end{tabular}

表 6 外膜浸潤の程度と 5 生例

\begin{tabular}{c|r|r|r}
\hline & 5 生例 & \multicolumn{1}{c|}{$\begin{array}{c}\text { 5 年以内 } \\
\text { 死亡例 }\end{array}$} & 5 生率 \\
\hline a0 & $44(45.8 \%)$ & $75(20.1 \%)$ & $(37.0 \%)$ \\
a1 & $16(16.7 \%)$ & $96(25.7 \%)$ & $(13.9 \%)$ \\
a2 & $28(29.2 \%)$ & $117(31.3 \%)$ & $(19.3 \%)$ \\
a3 & $8(8.3 \%)$ & $86(22.9 \%)$ & $(8.7 \%)$ \\
\hline 計 & 96 & 374 & \\
\hline
\end{tabular}

以内死亡例では20.1\%であり，明らかな差が認められ た.

癌漫潤が䇨層までにとどまっていることは長期生存 の大きな因子である。

組織学的リンパ節転移：5生率との関係は $\mathrm{n}_{0}$ が明 らかに良い生存率で, $\mathrm{n}_{1}$ と $\mathrm{n}_{2}$ の間には差がなく， $\mathrm{n}_{3}$ 以 上になると極端に低下寸る（表 7 ）。， $\mathrm{n}_{0}$ は 5 生例では $67.7 \%$ 占め，5年以内死亡例では $33.6 \%$ ある。 ま た， $\mathrm{n}_{3}$ 以上に転移の認められたのは，5生群では $3.1 \%$

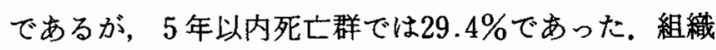
学的に確認されたリンパ節転移のないことが，長期生 存の大きな因子であることを示している.また, $\mathrm{n}_{3}$ 以上 に転移のある症例の予後が悪いことを物語っている。

組織型：紙織型別に 5 生率をみると，表 8 にみられ るように高分化型と中分化型との間には差がなく，低 分化型になると低値を示している．5生例は 5 年以内 死亡群に比べて高分化型の頻度がやや高く，低分化型 の頻度がやや低いが，著明な差ではない。

組織学的放射線治療効果：術前治療を行った症例で 治療効果を組織学的にみて, 食道癌取扱い規約に従っ て分類したのが表 9 である. Ef 3はEf 1に比べて約 4 倍高い 5 生率を示している. 5 生例は 5 年以内死亡群 そ比較して Ef 1 頻度は低く, Ef 3 の頻度は高い. Ef 2は同頻度である.非照射群は比較的早期の症例がふく まれているのであるが, Ef 3群はこれより高い5生率 を示している. 局所的治療である術前照射の組織学的

表 7 リンパ節転移の程度と 5 生例

\begin{tabular}{c|r|r|c}
\hline & 5 生例 & $\begin{array}{c}\text { 5 年以内 } \\
\text { 死亡例 }\end{array}$ & 5 生率 \\
\hline $\mathrm{n} 0$ & $65(67.7 \%)$ & $120(33.6 \%)$ & $(35.1 \%)$ \\
$\mathrm{n} 1$ & $7(7.3 \%)$ & $39(10.9 \%)$ & $(15.2 \%)$ \\
$\mathrm{n} 2$ & $21(21.9 \%)$ & $93(26.1 \%)$ & $(18.4 \%)$ \\
$\mathrm{n} 3-$ & $3(3.1 \%)$ & $105(29.4 \%)$ & $(2.8 \%)$ \\
\hline 計 & 96 & 357 & \\
\hline
\end{tabular}

表 8 組織型と 5 生例

\begin{tabular}{l|c|r|c}
\hline & 5 生例 & \multicolumn{1}{|c|}{$\begin{array}{c}5 \text { 年以内 } \\
\text { 死亡例 }\end{array}$} & 5 生率 \\
\hline 高分化扁平上皮癌 & $39(40.6 \%)$ & $141(37.7 \%)$ & $(21.7 \%)$ \\
中分化" & $39(40.6 \%)$ & $152(40.7 \%)$ & $(20.4 \%)$ \\
低分化 " & $13(13.6 \%)$ & $63(16.8 \%)$ & $(17.1 \%)$ \\
未分化癌 & 0 & $7(1.9 \%)$ & $(0 \%)$ \\
その他 & $5(5.2 \%)$ & $11(2.9 \%)$ & $(31.3 \%)$ \\
\hline \multicolumn{1}{c|}{$\quad$ 計 } & 96 & 374 & \\
\hline
\end{tabular}


表 9 術前照射の組織学的効果子 5 生例

\begin{tabular}{l|l|r|r}
\hline & 5 生例 & $\begin{array}{c}\text { 5 年以内 } \\
\text { 死亡例 }\end{array}$ & 5 生率 \\
\hline Ef 1 & $18(18.8 \%)$ & $161(43.0 \%)$ & $(10.1 \%)$ \\
Ef 2 & $31(32.3 \%)$ & $120(32.1 \%)$ & $(20.5 \%)$ \\
Ef 3 & $20(20.8 \%)$ & $31(8.3 \%)$ & $(39.2 \%)$ \\
非照射 & $27(28.1 \%)$ & $62(16.6 \%)$ & $(30.3 \%)$ \\
\hline \multicolumn{1}{c|}{ 計 } & 96 & 374 & \\
\hline
\end{tabular}

効果の著しいほど 5 生率が高いのは興味深い。

5 生例の死因： 5 年以上生存して死亡したすのが32 例ある。これらの死因を検討したのが表10である。不 明例が16例と多いが，これは遠隔地に住んでおり，受 診の間隔が長くなった死亡前の受診では再発の徵候が なく，高秢によると考光られるものが汪とんどである。 膿胸が 1 例, 肺炎によるものが 2 例あった。術後の肺 機能低下が一因となっているものと考兄られる。心発 作によるるのが 1 例あった.

放射線脊䯣炎による 1 例は，手術を拒否して50Gy の照射を行い， 1 年後に局所再発がみられたため切除 手術を行った。術後 4 年 6 月で放射線替㗙炎を発症し て発行し, 術後 5 年 2 月で死亡したものである.

再発に上る死亡は 3 例で 5 生例 96 例の $3.1 \%$ に当る. 今までは食道癌は 2 年経過すると再発は少いといわれ

表10 5 生例の死因

\begin{tabular}{lr}
\hline 再発 & 3 \\
重複癌 & 7 \\
膿胸 & 1 \\
肺炎 & 2 \\
心不全 & 1 \\
放射線筒煘炎 & 1 \\
不明 & 16 \\
\hline
\end{tabular}

て来たが， 5 年経過例にも再発があるので，この時期 でも再発の早期発見と治療が必要であることを示して いる，再発部位は縦隔と脊柱であった。

他葴器の重複癌を発病したのが10例ある。２例は生 存中, 1 例は他病死で, 7 例は重複癌に上る死亡であっ た. 胃癌 3 例, 肝癌 1 例, 肺癌 1 例, 前立腺癌 1 例, 白血病 1 例であった。再発よりも他藏器の重複癌によ る死亡の方が多い事実は興味深い。

癌再発生存例: 術後に癌の再発があり, 適切な治療 を行ったので食道の手術後 5 年以上生存したのが 9 例 ある。これらの症例の一覧表を表11に示した。再発衣 での期間は短いものは 8 月，長いものは 7 年 1 月で あった， 4 例に手術，5例に放射線治療を行っている。 手術を行ったのは断端再発が 2 例, 頸部リンパ節が 1 例，肺が 1 例であった. 断端再発の 1 例は術前照射後 切除し, Ef 3であったが 1 年11月後に断端再発がみら れ，他の 1 例は胸部上部の腫瘤型の $\mathrm{sm}$ 癌であったが ieがあり， 7 年 1 月後に再発した. 放射線治療は縦隔 3 例, 断端再発 1 例, 頸部リンパ節 1 例に行われた。 症例 9 は肺之脳に 2 回に渡り転移再発がみられ，いず れも外科切除を行った。

これをまとめたのが表12である。断端再発は 3 例に みられ 2 例が生存している. 綎隔の 3 例はいずれも死 亡したが，らち 1 例は肝転移によるものである。頸部 リンパ節の 2 例と肺の 1 例はいずれも生存している. この結果からみると, 断端再発や頸部リンパ節の転移 の中には, 他臓器への転移がなく, 適切な治療により 長期生存する可能性のある症例があることを示してい る.

時期別 5 生率：病院開設以来の症例をむとめたので あるから，後期になる程医療技術の進歩により，5生 率も向上するものと考えて 5 年ごとに区切って検討し

表11 再発を有する 5 生例

\begin{tabular}{|c|c|c|c|c|c|}
\hline 症例 & 場所 & 間隔 & 再発の治療 & 結 & 果 \\
\hline 1 & 断端 & 1 年11月 & 手術 & \multicolumn{2}{|c|}{7 年 9 月 $+($ 非癌化 $)$} \\
\hline 2 & 綎隔 & 5 年 & 放射線 & \multicolumn{2}{|c|}{6 年 5 月十( 縦隔 $)$} \\
\hline 3 & " & 3 年 & "I & \multicolumn{2}{|c|}{5 年 6 月十 + (肝転移) } \\
\hline 4 & 頸部リンパ節 & 8 月 & 手術 & 12年 9 月 & 生存 \\
\hline 5 & 縱隔 & 5 年 & 放射線 & \multicolumn{2}{|l|}{5 年 2 月十 } \\
\hline 6 & 断端 & 7 年 1 月 & 手術 & 9 年 & 生存 \\
\hline 7 & " & 1 年 & 放射線 & 7 年11月 & $"$ \\
\hline 8 & 頸部リンパ節 & 2 年 8 月 & "I & 7 年 9 月 & " \\
\hline \multirow[t]{2}{*}{9} & 肺 & 3 年 9 月 & 手術 & 6 年 3 月 & " \\
\hline & 脳 & 5 年 9 月 & " & 6 年 3 月 & " \\
\hline
\end{tabular}


表12 再発(部位別)を有する 5 生例

\begin{tabular}{l|c|c|c}
\hline & 症例 & 生存 & 死亡 \\
\hline 断端 & 3 & 2 & 1 \\
綎隔 & 3 & 0 & 2 \\
鎖骨上リンパ節 & 2 & 2 & 0 \\
肺 & 1 & 1 & 0 \\
\hline
\end{tabular}

表13 時期別 5 生率

\begin{tabular}{c|c|c}
\hline & 生存者 & 生存竜 \\
\hline $1962-1966$ & 6 & 11.4 \\
$1967-1971$ & 37 & 22.7 \\
$1972-1976$ & 41 & 24.1 \\
$1977-1978$ & 10 & 13.5 \\
\hline
\end{tabular}

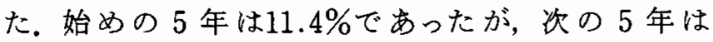
$22.7 \%$ ，その次は $24.1 \%$ と向上した。最後は 2 年であ るが意に反して $13.5 \%$ と低下した。この 2 年は進行癌 の比率が特に多い年であった．従って 5 生率は 25 30\%采で行くが，それ以上の成績の向上は早期発 見によるものと考えられた（表13）.

\section{4. 考察}

食道癌の治療については種々の努力が行われている が，報告されている治療成績は满足すべき段階からは 程遠い，奥平1)は九大第 2 外科に拈ける昭和 40 年から 昭和54年までの 15 年間の耐術例138例の 5 生率は 15.1\%と報告している。 また井手ら 2 は1965～1975に おける東京女子医大消化器病七ンターの食道癌切除例 616例の 5 生率が $22.1 \%$ とのべている.

また1969〜1973年の全国食道がん登録調查報告3)の 耐術例1,371例の 5 生率は $22.01 \%$ でった。われわ れ゙) 1962年から1978年までに国立がんセンターにお いて切除手術を行った 490 例のうち耐術例 451 例の 5 生 率は24.3\%，10生率は18.3\%と報告している。また， この論文において 5 生率を左右する因子について検討 した結果をのべた。

今回は1962年から1978年12月までに切除手術を行っ た 470 例を， 5 年生存例 96 例と， 5 年以内死亡例 374 例 とに分けて，種々の因子について比較検討を行った。

その結果，女性は男性と比較して 2 倍以上の 5 生率 を示し， 5 生例の中で占める率が， 5 年以内で死亡す る例よりはるかに大で，女性であることが術後の生存 に大きな影響をもっていることが明らかになった。

年齢は予想に反して若年者の方が良い生存率を示し た．従って若年者食道癌では，より積極的な手術を行
らべきであることを示す一つの論拠を示したものであ ろら.

組織学的外膜浸潤の程度は 5 生率および 5 生例の中 に占める割合いと比較的良い相関関係を示した。併し， $a_{1}$ と $a_{2}$ との間には差がなかった。これは全国食道がん 登録調查報告3)の結果とも一致している。

組織学的リンパ節転移は 5 生率， 5 生例の中の比率 とも良く一致する， $\mathrm{n}_{1}$ が $\mathrm{n}_{2}$ より低値であったのは，術 前照射例が含まれているために, $\mathrm{n}_{1}(+)$ が少なかった ことに原因が求められよう。

今回の調查で興味のあったのは 5 年以上生存した例 の死因である，先にのべたように，高跉者であるため に，再発不明で死亡した例が多くみられるが，これを 除外すると，再発例よりは重複癌による死亡が多く認 められたことである.胃癌がその中で多くみられるが， 一つの癌に罹患した症例は，他の癌に対しても高危険 群に属していることを物語っている。この中の 1 例は 食道癌手術後に喉頭, 舌, 口腔底に癌が発生している。 この事から，われわれは食道癌の手術を行った後に， 5 年経過して予後の良い症例では，再発もさることな がら, 新たに発生する他臓器の癌をチェックする必要 があることを示している，特に日本人には胃癌が多い ことから，再建胃管に対する注意が必要であろう5)。

また, 術後再発を起しながら, 適切な時期適当な治 療を行ったため， 5 年以上生存した例が 9 例も認めら れた。この結果は, 術後の経過観察で，いか炕して速 い時期に再発を発見するかが重要であることを示す事 実である，ただ慢然と観察するのではなく，重点を定 めて観察することが必要であろう。すなわち, 切除断 端や，上縦隔，鎖骨上リンパ節，肺などへの転移の チェックが重要であろう。

\section{5.まとめ}

食道癌切除症例を， 5 生例と 5 年以内死亡例とに分 けて考察した。 その結果，5年生存については，女性 であること，外膜浸潤やリンパ節転移のないことが重 要な因子であることが判明した。

また，5年生存例の死因についてみると，再発より は他藏器の重複癌によるものが多いことがわかった。 この事は患者の術後の経過を観察する場合に，長期に なればなるほど，再発と同時に重複癌に対するチェッ クが重要であることを示している．日本人であるから 胃，すなわち再建胃管に癌が発生したかどらかを観察 することが重要である。 


$$
\text { 文献 }
$$

1）奥平恭之, 杉町圭蔵, 上尾裕昭ほか：食道癌治療の 現況. 日外会誌 $81: 1552-1558,1980$

2）井手博子, 遠藤光夫 : 食道腫瘍の臨床病理. 東京, 医学書院，p3，1984

3）食道疾患研究会：全国食道がん登録調查報告. 3 号，国立がんセンター，東京，1982
4）飯塚紀文, 加藤抱一，渡辺 寛ほか：食道癌の治療 成績とそれを左右する因子。癌の臨 $27: 840$ $-845,1981$

5）飯塚紀文, 平田克治, 塩貝陽而ほか：食道癌根治手 術後の再建胃管癌の 2 症例と重複癌に対する考 察。胃之腸 $12: 433-437,1977$ 